\title{
PODRIDÃO BASAL PÓS-COLHEITA DO COCO VERDE NO ESTADO DO CEARÁ
}

\author{
FRANCISCO M. P. VIANA ${ }^{1}$, FRANCISCO C. O. FREIRE ${ }^{1}$, BEATRIZ M. BARGUIL ${ }^{2}$, RICARDO \\ E. ALVES ${ }^{1}$, ANTONIO A. SANTOS ${ }^{1}$, JOSÉ E. CARDOSO ${ }^{1}$ \& JULIO C. VIDAL ${ }^{1}$
}

Embrapa Agroindústria Tropical, Cx. Postal 3761, CEP 60511-110, Fortaleza, CE, e-mail: fmpviana@cnpat.embrapa.br;

${ }^{2}$ Centro de Ciências Agrárias-UFC, Cx. Postal 12168, CEP 60021-970, Fortaleza-CE

(Aceito para publicação em 05/07/2002)

Autor para correspondência: Francisco M. P. Viana

\section{ABSTRACT \\ Post-harvest basal rot of coconut fruits in the State of Ceará, Brazil}

A new post-harvest disease of coconut (Cocos nucifera) was recently detected in fruits exported to European countries. The main symptoms are the blacking and cracking of basal parts of the fruits. Water oozing may occurs as the infection progresses. The fungus
Lasiodiplodia theobromae has been frequently isolated from the lesions. Inoculation tests proved that this pathogen is the causal agent of the coconut fruit basal rot. This is the first occurrence of this post-harvest disease in Brazil.
Em meados de 2001, o Grupo do Coco do Ceará (GCC) iniciou a exportação de coco verde para a Europa. Esses frutos foram envolvidos, individualmente, com filme plástico de cloreto de polivinila (PVC) para proteção contra os efeitos do frio, tais como a perda de peso e o enrugamento. Os frutos foram transportados em containers $\mathrm{a} \pm 12{ }^{\circ} \mathrm{C}$ por um período de 15 dias, até o destino. No destino detectou-se um grande número de frutos com uma podridão escura na região basal, o que causou considerável prejuízo. Posteriormente, colheu-se frutos na mesma região daqueles exportados, submetendo-os à câmara úmida (100\% U.R $\mathrm{e} \pm 30^{\circ} \mathrm{C}$ ), para propiciar condições favoráveis ao agente causal associado. Dez dias após, os sintomas foram reproduzidos nesses frutos. A doença se caracterizou por um escurecimento na região basal, logo abaixo das brácteas. Com o passar dos dias, a lesão tornou-se visível: era escura e margeava as brácteas (Figura 1A). Embora o início da colonização do fruto pelo patógeno não seja visível, o ataque pode ser revelado por uma anasarca que antecede a necrose e forma uma nítida linha demarcatória entre o tecido afetado e o tecido sadio. Cerca de $48 \mathrm{~h}$ após o aparecimento da anasarca, a área correspondente a esta escurece, tornando-se marrom clara no início, e depois quase preta, enquanto a anasarca avança para os tecidos sadios. É comum a exsudação de albume líquido na forma de uma gota junto às brácteas (Figura 1-B), devido à atividade necrotrófica do patógeno que desagrega os tecidos na região e estes não mais suportam a elevada pressão interna. Removendo-se as brácteas, é possível encontrar sinais do patógeno na forma de um micélio branco-acinzentado na região do cálice. Um corte transversal nessa região, logo abaixo das brácteas, revela a colonização do patógeno através do mesocarpo escurecido (Figura 1-C). Em lesões velhas, pode-se observar, outro sinal do patógeno na forma de numerosos cirros projetados dos picnídios (Figura 1-D). Um fungo associado a essas lesões foi isolado em meio BDA. O teste de patogenicidade foi realizado com cinco cocos verdes, colhidos de área sadia, dos quais se retirou três secções da região próxima às brácteas, pôs-se em contacto com o crescimento do fungo nas placas e, em seguida, devolveu- se estas secções aos respectivos locais e frutos. A testemunha constou do emprego de secções mergulhadas em água destilada e esterilizada. Os frutos inoculados foram incubados a temperatura de $28 \pm 2{ }^{\circ} \mathrm{C}$ por 12 dias. Cinco dias após a inoculação, iniciou o escurecimento da superfície da casca na região próxima aos pontos de inoculação e, 11 dias depois, os sintomas foram reproduzidos como relatado. $\mathrm{O}$ agente causal foi reisolado em placas com meio BDA, incubadas a $28 \pm 2{ }^{\circ} \mathrm{C}$ com fotoperíodo de $12 \mathrm{~h}$ durante 15 dias. Porções da colônia observadas ao microscópio ótico, revelaram a presença de picnídios com conídios jovens hialinos, unicelulares e de parede celular delgada dupla, que se tornavam escuros e bicelulares quando maduros, medindo cerca de 24,5 X 13,0 $\mu \mathrm{m}$, concluindo que o patógeno era Lasiodiplodia theobromae (Pat.) Griff. \& Maubl. (= Botryodiplodia theobromae Pat.) (BARNETT \& HUNTER. Illustrated genera of imperfect fungi. 1998; ROGER. Encyclopédie micologique: Phytophatologie des pays chauds, 1953; SUTTON. The Coelomycetes, 1980.).

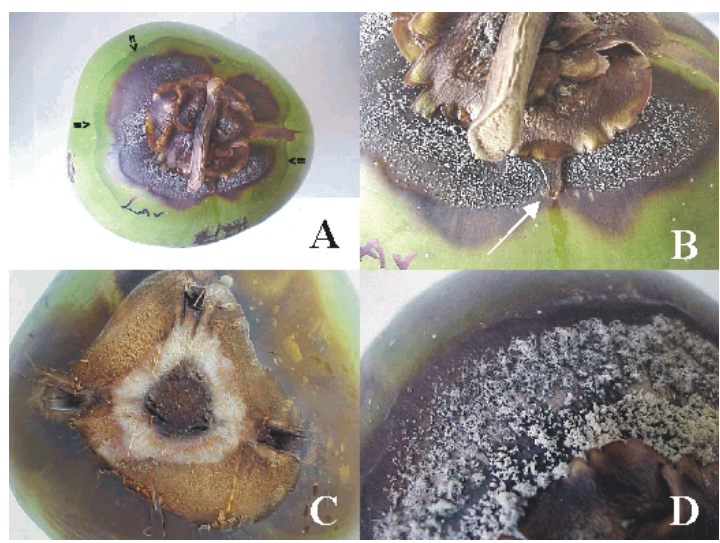

FIG. 1 - Fruto verde do coqueiro (Cocos nucifera) anão afetado por Lasiodiplodia theobromae. A-lesão basal escura com anasarca; B-exsudação de albume líquido; Cmesocarpo descolorido de um fruto inoculado; Dcirros lançados de picnídios a partir de lesão velha. 